\title{
CRYSTALLIZATION OF FERROUS SULFATE HEPTAHYDRATE FROM SPENT PICKLE LIQUOR BY ADDITION OF TERTIARY BUTYL ALCOHOL
}

\author{
M.F. El-Sherbiny \\ Basic Engineering Sciences Dept., Faculty of Engineering, \\ Menoufia University
}

\section{ABSTRACT:}

Ferrous sulfate heptahydrate (copperas) was recovered by treating spent pickle liquor with tertiary butyl alcohol. Yields of crystallized ferrous sulfate heptahydrate were calculated for different concentrations of liquior at temperature of $25 \& 35^{\circ} \mathrm{C}$. It is concluded that for the most complete recovery of ferrous sulfate heptahydrate from waste pickle liquor by adding tertiary butyl alcohol, the $\mathrm{H}_{2} \mathrm{SO}_{4}$ concentration should be as low as possible, the $\mathrm{FeSO}_{4}$ concentration as high as possible, the alcohol to liquor volumetric ratio of $2: 1$ and temperature of $25^{\circ} \mathrm{C}$. For a liquor containing $135 \mathrm{~g} / \mathrm{l}$ of $\mathrm{FeSO}_{4}$ and $40 \mathrm{~g} / 1$ of $\mathrm{H}_{2} \mathrm{SO}_{4}$, the yield was $94.2 \%$ using $2: 1$ volumetric ratio at $25^{\circ} \mathrm{C}$.

Key Words: Waste pickle liquor, Pickling of steel, ferrous sulfate heptahydrate (copperas).

\footnotetext{
Manuscript received from Dr. M.F. El-Sherbiny

Accepted on : $16 / 6 / 2001$

Engineering Research Journal Vol 24,No 3, 2001 Minufiya University, Faculty of

Engineering, Shebien El-Kom , Egypt , ISSN 1110-1180
} 


\section{INTRODUCTION:}

Steel pickling waste liquors are considered a water pollutant. The recovery of steel pickling waste liquors ${ }^{[1]}$ is one of the main environmental aspects that the steelmaking industry must resolve. There are ${ }^{[2]}$ several processes for the treatment of sulfuric liquors. Coninuous recovery of pickle liquors saves acid and reduces waste treatment expenses as well as providing a means of decreasing pickling times.

Acid pickling ${ }^{[3-14]}$ of steel is considered a preliminary chemical process carried out to remove iron oxides from steel surfaces, prior to coating processes such as painting, electroplating, phosphating, enameling etc. Most steel products are pickled using acids such as sulfuric acid, hydrochloric acid, phosphoric acid and hydrofluoric acid. Sulfuric acid has traditionally been the pickling medium for descaling steel. Steel products are treated with a dilute sulfuric acid for a few minutes sufficient to dissolve the surface oxides. The effectiveness of sulfuric acid pickling liquor is reduced as ferrous sulfate is formed. Fresh sulfuric acid must be continuously added to restore the activity of the pickling solution. Over time, the activity of the pickling liquor becomes weak such that it needs to be totally replaced with fresh acid. Waste pickle liquor ${ }^{[15]}$ contains about $134 \mathrm{~g} / 1$ ferrous sulfate and $33 \mathrm{~g} / \mathrm{l}$ sulfuric acid.

Previous studied showed that ferrous sulfate was recovered by heating or cooling waste pickle liquors ${ }^{[16-21]}$. Treatment of waste pickle liquous with acetone ${ }^{[22-26]}$, ethyl alcohol ${ }^{[27]}$, iso-propyl alcohol ${ }^{[28]}$ and 1-propanol ${ }^{[29]}$ were studied to crystallize ferrous sulfate heptahydrate. The object of the present work is to crystallize $\mathrm{FeSO}_{4} .7 \mathrm{H}_{2} \mathrm{O}$ by addition of tertiary butyl alcohol.

\section{EXPERIMENTAL:}

The liquors used throughout this work were prepared by dissolving the required amounts of sulfuric acid and ferrous sulfate hepatahydrate in distilled water. The concentrations studied weie $27,54,81,108,135$ and $162 \mathrm{~g} / 1$ ferrous sulfate in presence of $10,20,40,60$ and $80 \mathrm{~g} / 1$ of sulfuric acid. To a certain volume of the liquor tertiary butyl alcohol was added slowly with stirring during addition. The time of addition was about two minutes, the crystallized ferrous sulfate heptahydrate crystals were then filtered. The factors studied which may affect the yield of crystallized ferrous sulfate heptahydrate during crystallization were the concentration of the liquors, tertiary butyl alcohol to liquor volumetric ratio and temperature. The variations in the volumetric ratio 
of tertiary butyl alcohol to liquor affect the yield of crystallized product ferrous sulfate heptahydrate. The volumetric ratios studied were 1:1, 2:1 and 3:1. Crystallization was carried out at 25 and $35^{\circ} \mathrm{C}$ at different concentrations and different volumetric ratios.

After filtration, ferrous sulfate was analyzed to determine its yield and the water content of the crystals. Ferrous and sulfate ions were determined according to standard methods ${ }^{[30]}$. It was found that water content is seven moles of $\mathrm{H}_{2} \mathrm{O}$ per mole of $\mathrm{FeSO}_{4}$ and thus the ferrous sulfate produced was heptahydrate in all experiments. The results of the experiments are shown in figures $(1-15)$

\section{RESULTS AND DISCUSSION:}

\section{Effect of sulfuric acid concentration:-}

The results shown in figures (1-14) indicate that the yield of crystallized ferrous sulfate heptahydrate is dependent on the acid concentration. It was found that increasing the acid concentration decreases the yield of $\mathrm{FeSO}_{4} .7 \mathrm{H}_{2} \mathrm{O}$ at constant volumetric ratio, constant ferrous sulfate concentration and constant temperature. For a liquor of $135 \mathrm{~g} / \mathrm{l}$ $\mathrm{FeSO}_{4}$, using $2: 1$ volumetric ratio and temperature of $25^{\circ} \mathrm{C}$, the percentages of recovery vary in the order $96.2,95.194 .2,92.4$ and $91 \%$ at acid concentrations of $10,2040,60$ and $80 \mathrm{~g} / 1$ respectively. It is known that waste pickle liquor is removed at about $40 \mathrm{~g} / \mathrm{l}$ $\mathrm{H}_{2} \mathrm{SO}_{4}$, so it is practically to crystallize ferrous sulfate at this acid concentration.

It can be concluded that to obtain maximum recovery of ferrous sulfate heptahydrate, liquors of minimum acid concentration must be used.

\section{Effect of ferrous sulfate concentration:-}

The results shown in Figures (1-15) indicate that increasing the ferrous sulfate concentration increases the yield of crystallized $\mathrm{FeSO}_{4} \cdot 7 \mathrm{H}_{2} \mathrm{O}$. Using $2: 1$ volumetric ratio, the percentages of recovery vary in the order $63.2,80.8,89.0,91.4,94.2$ and $95 \%$ for liquors of $27,54,81,108,135$ and $162 \mathrm{~g} / \mathrm{FeSO}_{4}$ respectively at $25^{\circ} \mathrm{C}$ and acid concentration of $40 \mathrm{~g} / 1$ for all liquors.

It was found that, liquors with low ferrous sulfate concentrations give low yield of crystallized $\mathrm{FeSO}_{4} .7 \mathrm{H}_{2} \mathrm{O}$. The yield increases sharply, then slightly with increasing of ferrous sulfate concentration. The results show that the percentages of recovery are nearly independent on concentration for high ferrous sulfate concentrations. 


\section{Effect of tertiary butyl alcohol to liquor volumetric ratio:-}

It is clear from figures (1-15) that, increasing the volumetric ratio increases the recovery of ferrous sulfate hepatahydrate. The increase of volumetric ratio in the order $1: 1,2: 1$ and $3: 1$, the percentages of recovery increase in the order $66.9,94.2$ and $96.5 \%$ for a liquor of $40 \mathrm{~g} / 1 \mathrm{H}_{2} \mathrm{SO}_{4}$ and $135 \mathrm{~g} / 1 \mathrm{FeSO}_{4}$ at $25^{\circ} \mathrm{C}$. From these results, it is shown that, increasing volumetric ratio from 1:1 to $2: 1$ increases the percentages of recovery remarkably, but from 2:1 to $3: 1$ the recovery is increased slightly. The increase of recovery with increasing volumetric ratio may be attributed to the decrease of solubility of ferrous sulfate hepathydrate ir the system $\left(\mathrm{CH}_{3}\right)_{3} \mathrm{COH} \cdot \mathrm{H}_{2} \mathrm{SO}_{4}$. FeSO ${ }_{4} \cdot \mathrm{H}_{2} \mathrm{O}$.

\section{Effect of temperature:-}

It is clear from Figure (13) that increasing the temperature of crystallization decreases the yield of crystallized $\mathrm{FeSO}_{4} .7 \mathrm{H}_{2} \mathrm{O}$. The decrease at low ferrous sulfate concentrations is greater then that at high concentrations. For liquors of $108 \mathrm{~g} / 1 \mathrm{FeSO}_{4}$ and acid concentrations of $10,20,40,60$ and $80 \mathrm{~g} / 1$, the percentages of recovery are $95.7,94,91.3,89.7$ and $88.9 \%$ at $25^{\circ} \mathrm{C}$, but the percentages are $90.1,89.2,86.5,83.6$ and $80.5 \%$ at $35^{\circ} \mathrm{C}$ using volumetric ratio of $2: 1$. Because of the waste pickle liquor is removed at about $140 \mathrm{~g} / \mathrm{l}$ ferrous sulfate, the suitable temperature for crystallization of $\mathrm{FeSO}_{4} .7 \mathrm{H}_{2} \mathrm{O}$ is $25^{\circ} \mathrm{C}$.

\section{CONCLUSION:}

From the previous discussion of results, the recommended conditions for crystallization of ferrous sulfate heptahydrate using tertiary butyl alcohol are:-

1- Ferrous sulfate concentration between 135 and $162 \mathrm{~g} / \mathrm{l}$.

2- Sulfuric acid concentration between 20 and $40 \mathrm{~g} / \mathrm{l}$.

3- Tertiary butyl alcohol to liquor volumetric ratio of $2: 1$.

4- Temperature of $25^{\circ} \mathrm{C}$.

\section{REFERENCES:}

1- Dufour, J.; Latorre, R.; Alcala, EM.; Negro, C.; Formoso, A. and Lopez-Mateos, F., Journal of Magnetism \& Magnetic Materials V 157-158 pp 125-126 (1996).

2- Dufour, J.; Marron, JO.; Negro, C.; Latorre, R.; Formoso, A. and Lopez-Mateos, F., Chemical Engíneering Journal, 68, 2-3 pp 173-187 (1997). 
3- Ito, M.; Tachibana, R.; Seino, Y.; Yamamoto, A.; Kawabata, Y. and Uchino, Z., Japanese Journal of Applied Physics Part 1-Regular Papers Short Notes \& Review Papers 36, 12A pp 7404-7410 (1997).

4- Asrar, N. and Thakur, CP., Metal Finishing, 93, 2 pp 70-72 (1995).

5- Othmer, K. "Encyclopedia of Chemical Technology" $2^{\text {nd }}$ Edition, Interscience Publisher, N.Y. (1971).

6- Spanitz, J.R. and King, W., Iron \& Steel Engineer 74, 9 pp 17-21 (1997).

7- Docrnemann, Annika, G., Iron \& Steel Engineer 74, 1 pp 47-50 (1997).

8- McManus and Gcorge, J., Iron \& Steel Engineer 73, 6 pp 46-47 (1996).

9- Karner, W. and Hofkirchner, W., Metallurgical Plant \& Technology International 19,2 (1996).

10- Pielsticker, K.; Metallurgical Plant \& Technology International 18, 1 (1995).

11-Kani, Y.; Nakamura, T. and Ito. M., Hitachi Review 42, 4 pp 157-160 (1993).

12-Nakamura, T.; Tanaka, T.; Matsumoto, Y.; Nakane, Y. and Tani, K., Kobelco Tcchnology Review, N 16 pp 52-56 (1993).

13-Nesterenko, SA.; Nazarenko, VV.; Shevchenko, LA.; Shevchuk, LN. and Zorina, NE. Protection of Metals 25, 6 pp 750-753 (1990).

14- Jimba, T.; Iwadoh, S. and Izushi, T., Iron \& Steel Engineer 67, 3 pp 34-42 (1990).

15-El-Sherbiny M.F., M.Sc., (1980).

16- Niecko, J., Conservation \& Recycling 10, 4 pp 309-314 (1987).

17-Lackner, R.J., Chem. Abs. Vol. 74, 44603f (1971).

18-Babbel, H., Chem. Abs. Vol. 79, P 148705 K (1973).

19- Petcrson, J., Chem. Abs. Vol. 84, P $126461 d$ (1976).

20- Wailter, M., Chem. Abs. Voì. 58, P 12202 a (1963).

21-Jaroslav, P. and Vladimir, B., Chem. Abs. Vol. 63, $2656 \mathrm{~g}$ (1965).

22- Watanabe, A. and Kawakami. T., Chem. Abs. Vol. 55, 1975f (1961).

23- Watanabe, A.; Kawakami, T. and Moroto, S., Chem. Abs Vol. 59, 8384f(1963).

24-Ibid., Chem Abs. Vol. 68, 117035k (1968). 
25-Willmitzer, H., Austrian Pat. 363, 297 (1981).

26-Hussien, M.; Zatout, A.A., and Fathy, M., Afinidad 39, 35 pp 35-39 (1982).

27-Hussien, M. and Zatout, A.A., Chem. Petrochem. J. 11, 13 (1980).

28-El-Sherbiny, M.F.; Zatout, A.A. and Hussien M., The Egyptian Society of Chemical Engineers 24, 2 pp 44-51 (1998).

29-El-Sherbiny, M.F., The Egyptian Society of Chemical Engineers 26, 2 pp 76-83 (2000).

30- Vogel, I. "A Text Book of Quantitative Inorganic Analysis" $3^{\text {rd }}$ Edition, Longmans (1962) 


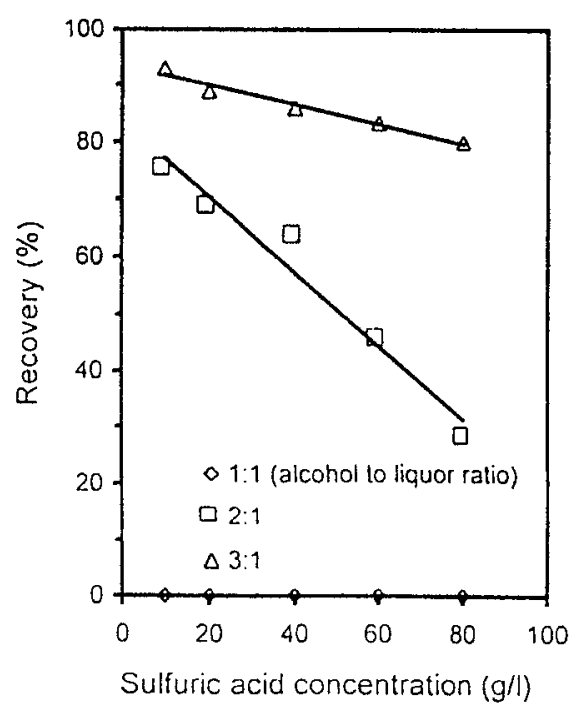

Fig. (1): Elfect of concentration of sulfuric acid and tertiary butyl alcohol to liquor rolumetric ratio on recovery of licrous sulfate heptahydrate. Conditions:

Ferrous sulfate conc. : $27 \mathrm{~g} / \mathrm{l}$ Temperature $\quad: 25^{\circ} \mathrm{C}$

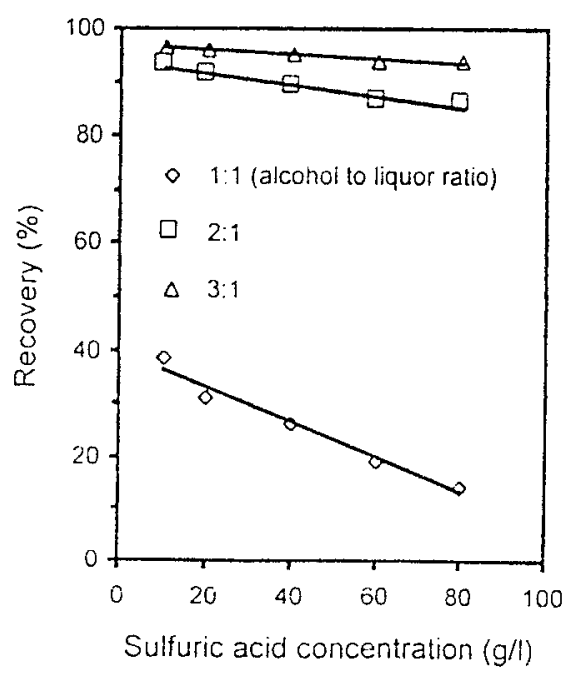

Fig. (3): Effect of concentration of sulfuric acid and certiary butyl alcohol to liquor volumetrie ratio on recovery of

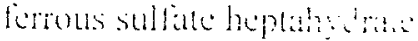

Conditions:

Ferrous sulfate conc: : $\$ 1 \mathrm{~g} / \mathrm{l}$

Temperature :25"C

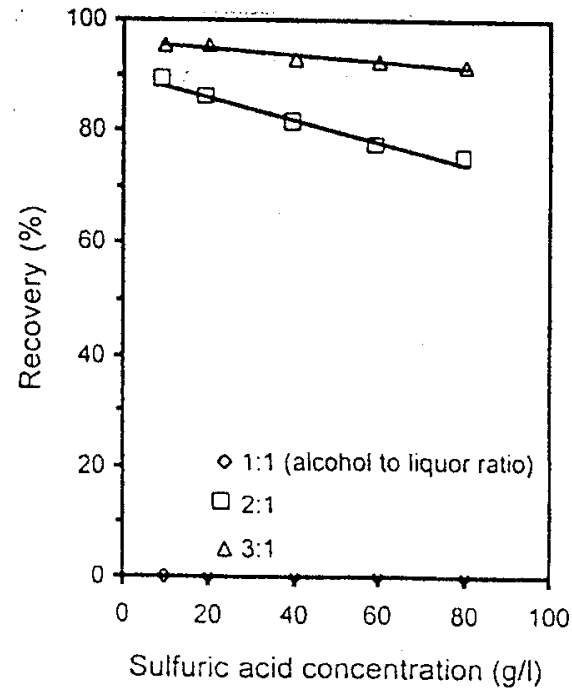

Fig. (2): Effect of concentration of sulfuric acid and tertiary butyl alcohol to liquor volumetric ratio on recovery of ferrous sulfate heptahydrate. Conditions:

Ferrous sulfate conc. : $54 \mathrm{~g} / 1$ Temperature $\quad: 25^{\circ} \mathrm{C}$

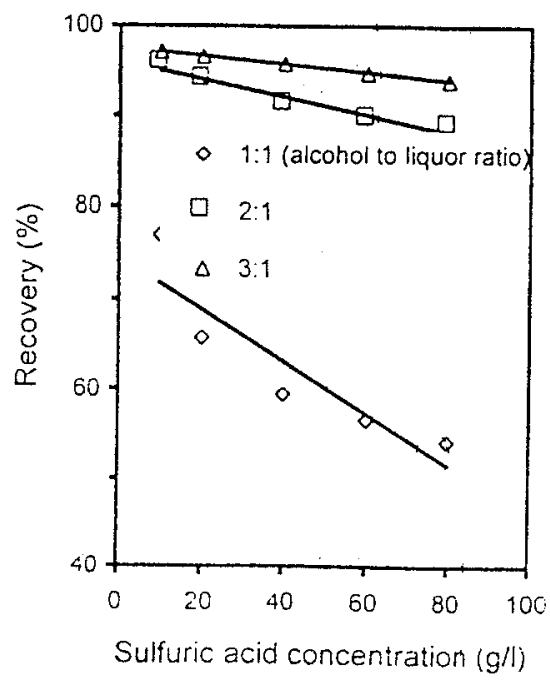

Fig. (4): Elfect of concentration of sulfuric acid and tertiary butyl alcohol wo liguor volumetric ratio on recovery of Eerrous sulfate iseptahydrate.

Conditions:

Ferrous sullate conc. : $108 \mathrm{~g} / 1$

Temperature $\quad: 25^{\circ 1} \mathrm{C}$ 


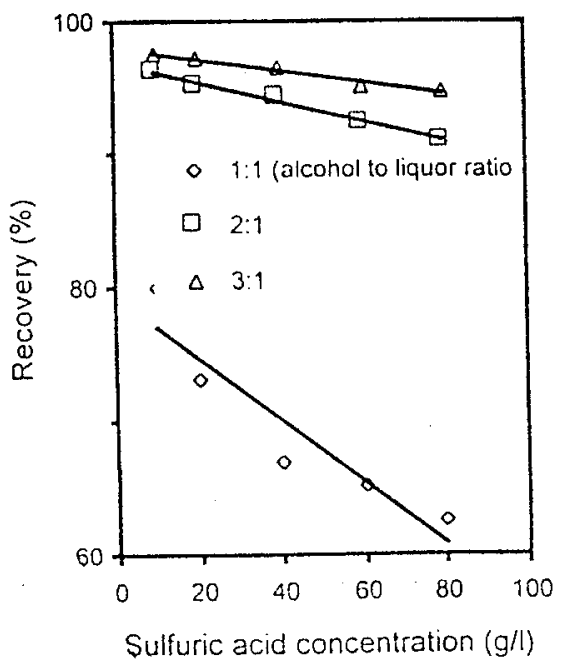

Fig. (5): Eflect of concentration of sulfuric acid and tertiatry butyl alcohol to liçuor volumetric ratio on recovery of Cerrous sullate heptahydrale. Conditions:

Ferrous sulfate conc. : $135 \mathrm{~g} / 1$

Temperature $\quad: 25^{\circ} \mathrm{C}$

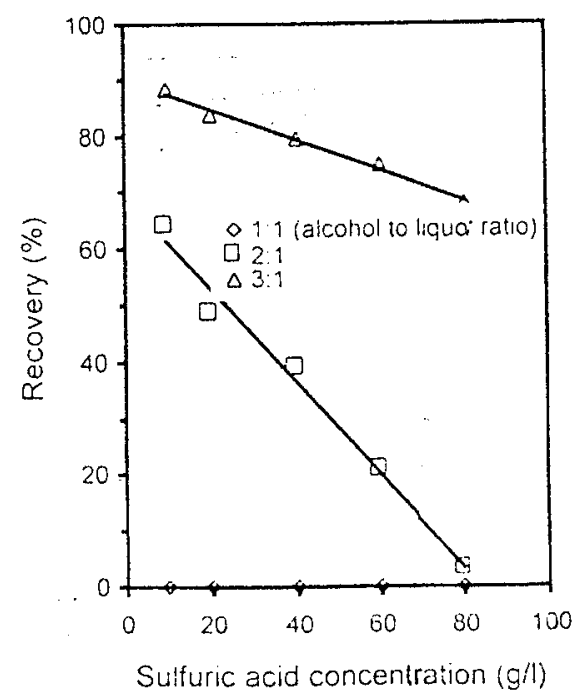

Fig. (7): leflect of concentration of sulfuric acid and certiary butyl alcohol to liquer solumetric ration on recosery of terrous sulfate heptahedrate. Conditions:

Forrous sulfale conc. : $27 \mathrm{~g} / \mathrm{l}$

Temperature $\quad: 35^{\circ 1} \mathrm{C}$

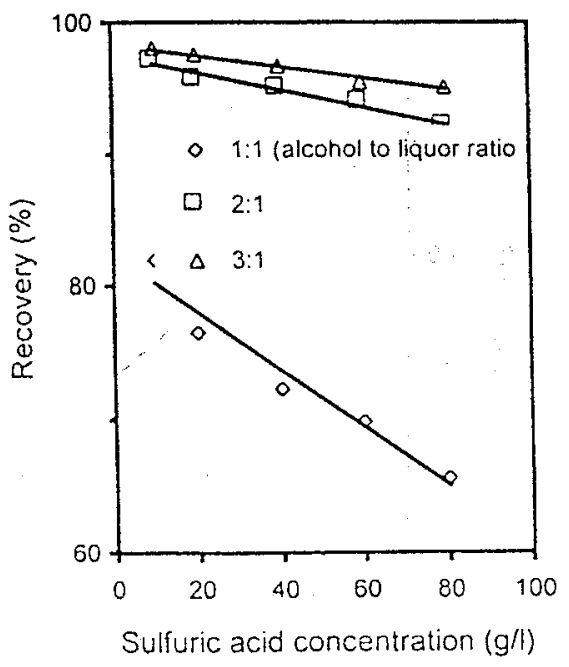

Fig. (6): Effect of concentration of sulfuric acid and tertiary butyl alcohol to liquor volumetric ratio on recorery of ferrous sulfate heptahydrate.

Conditions:

Ferrous sulfate conc. : $162 \mathrm{~g} / \mathrm{I}$

Temperature $\quad: 25^{\prime \prime} \mathrm{C}$

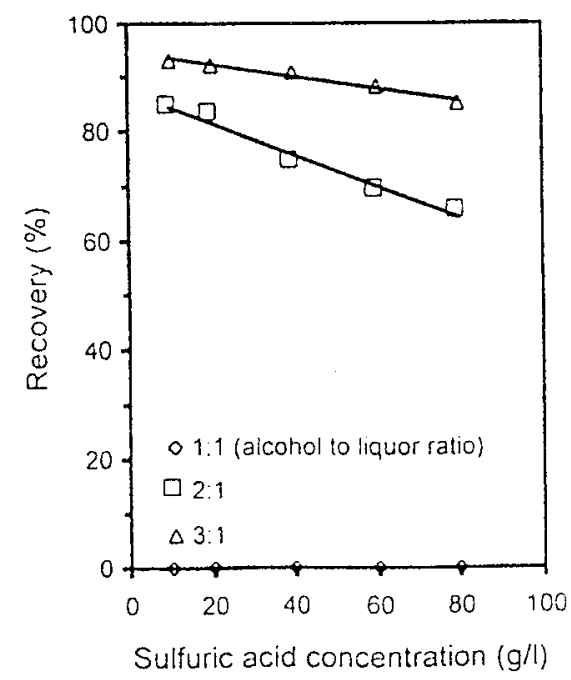

Fig. (8): Effect of concentration of sulfuric acid and tertiary butyl alcohol on liquor volumetric ratio on recorers of ferrous sulfate heptahydrate. Conditions:

Ferrous sulfate conc. : $5+2=1$ Femperature $\quad: 35 " \mathrm{C}$ 


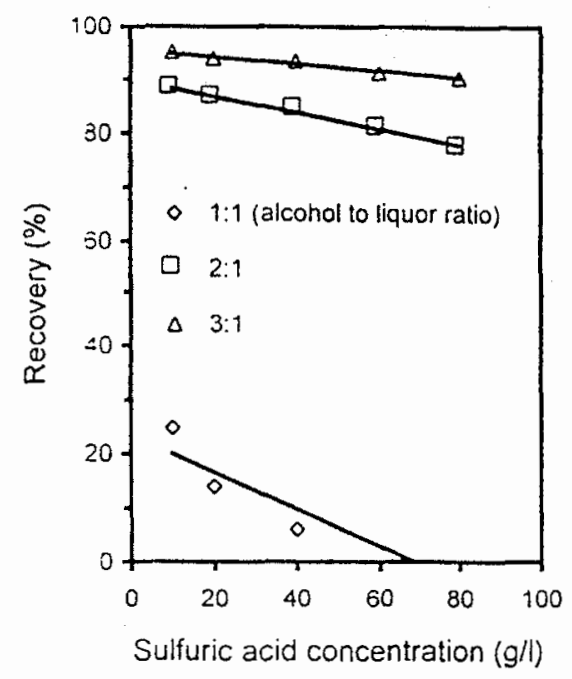

Fig. (9): Effect of concentration of sulfuric acid and tertiary butyl alcohol to liquor volumetric ratio on recovery of firrous sulfate heptahydrate.

Conditions:

Ferrous sulfate conc. : $81 \mathrm{~g} / 1$

Temperature $\quad: 35^{\circ} \mathrm{C}$

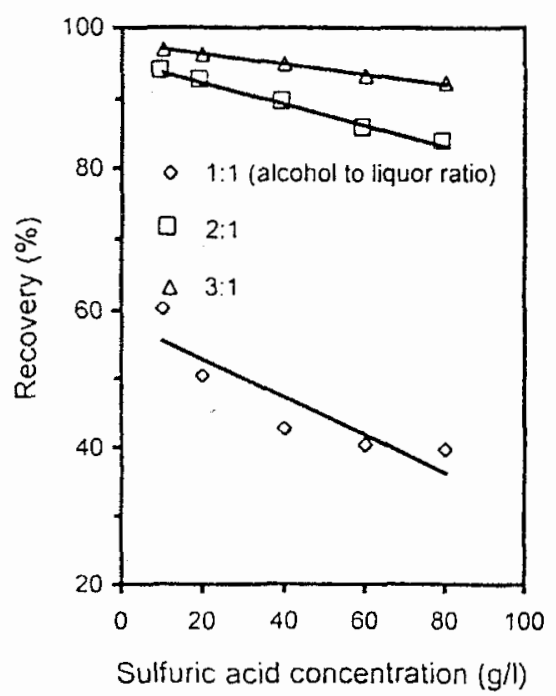

Fig. (11): Eflect of concentration of sulfuric acid and tertiary butyl alcohol to liquor volumetric ratio on recovery of ferrous sulfate heptahydrate.

Conditions:

Ferrous sulfate conc. : $135 \mathrm{~g} / \mathrm{l}$

Temperature $: 35^{-1} \mathrm{C}$

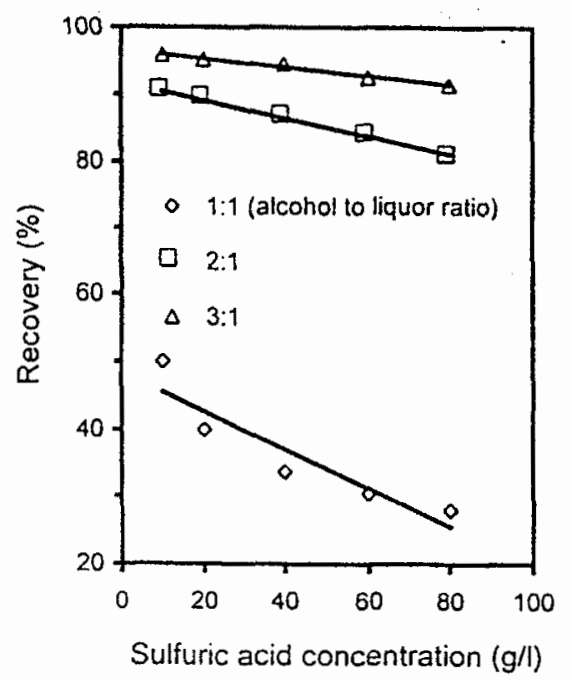

Fig. (10): Effect of concentration of sulfuric acid and tertiary butyl alcohol to liquor volumetric ratio on recovery of ferrous sulfate heptahydrate.

Conditions:

Ferrous sulfate conc. : $108 \mathrm{~g} / \mathrm{l}$

Temperature $\quad: 35^{\circ} \mathrm{C}$

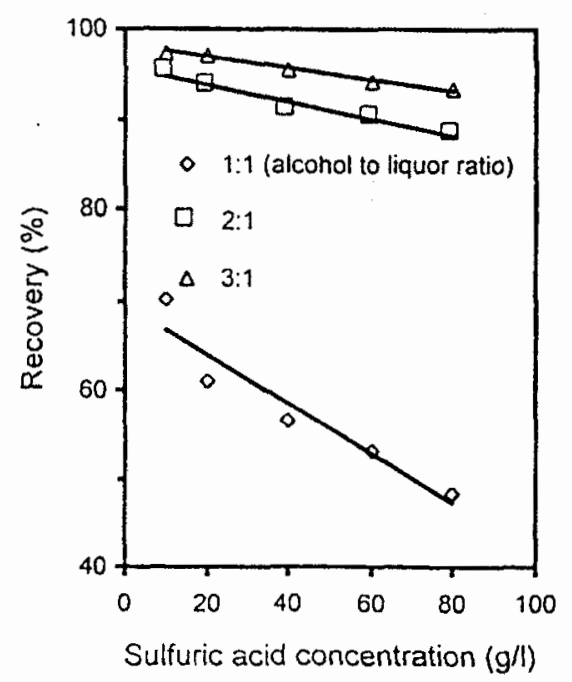

Fig. (12): Effect of concentration of sulfuric acid and tertiary butyl alcohol to liquor volumetric ratio on recovery of ferrous sulfate heptahydrate.

Conditions:

Ferrous sulfate conc. : $162 \mathrm{~g} / \mathrm{l}$

Temperature $\quad: 35^{\circ 1} \mathrm{C}$ 


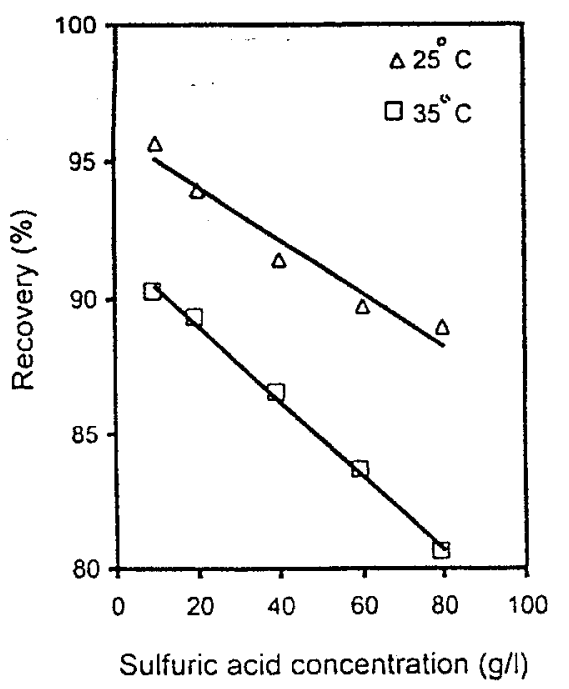

Fig. (13): Efrect of concentration of sulfuric acid and temperature on recovery. of ferrous sulfaie heptahydrate.

Conditions:

Ferrous sulfate conc. $\quad: 108 \mathrm{~g} / 1$

Tertiary butyl alcchol to liquor ratio: $2: 1$

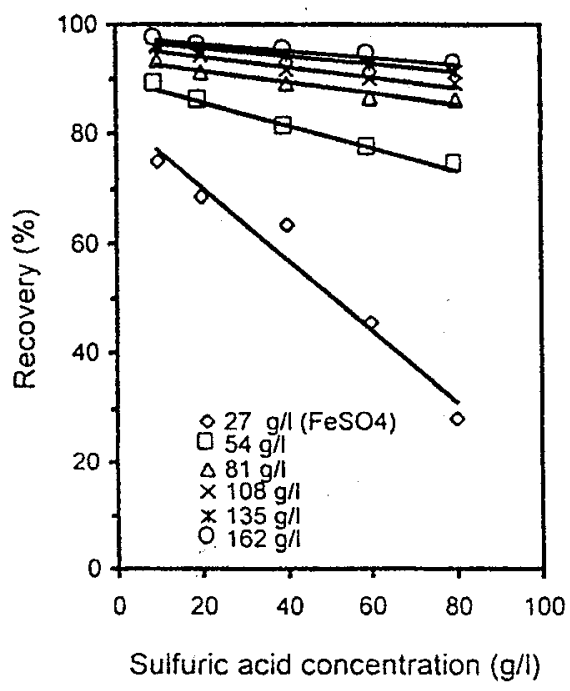

Fig. (14): Effect of concentration of sulfuric acid on recovery of ferrous sulfate heptahydrate at different ferrous sulfate concentrations.

Conditions:

Tertiary butyl alcohol to liquor ratio: $2: 1$

Temperature

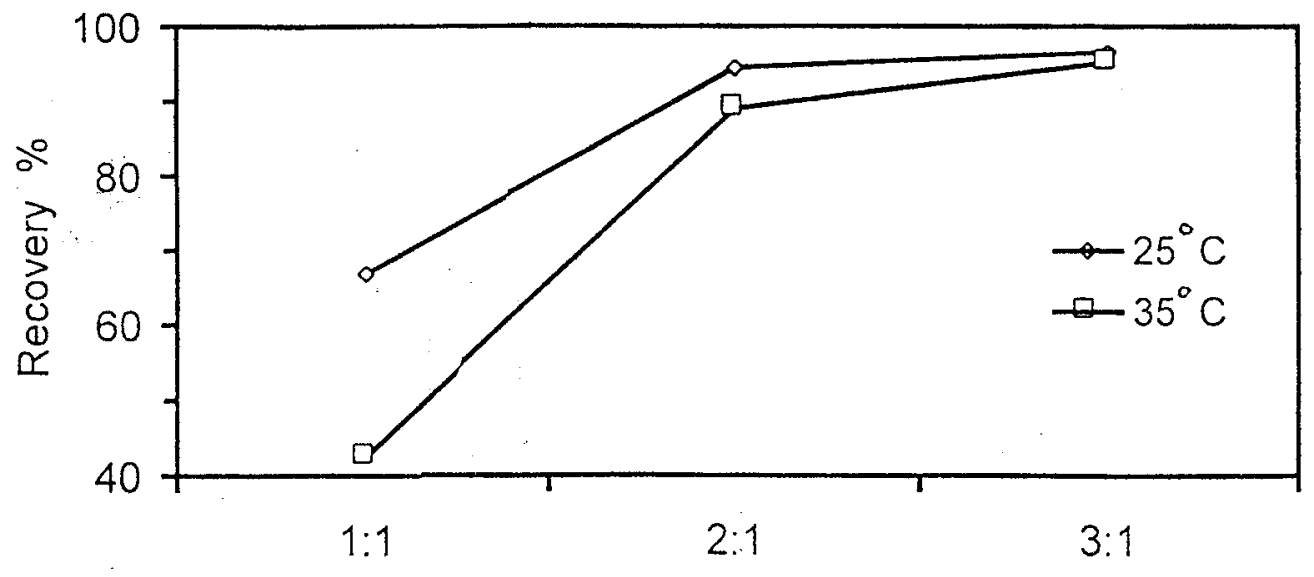

Tertiary butyl alcohol to liquor volumetric ratio

Fig. (15): Effect of tertia!y butyl alcohol to liquor volumetric ratio and temperature on recovery of ferrous sulfare heptahydrate.

Conditions:

Ferrous sulfate conc. $: 135 \mathrm{~g} / \mathrm{l}$

Sulfuric acid conc. $\quad: 40 \mathrm{~g} / \mathrm{l}$ 


\section{بلورة كبريتات الحديدوز سباعية الماء من مخلف \\ تخليل الصلب باضافة الكحول البيوتيلى الثلثى}

\section{محمد فتحي الشربيني}

قسم العلوم الأساسية الهندسية ـ كلية الهندسة ـ جامعة المنوفية

- تم استرجاع كبريتات الحديدوز سباعية الماء بمعالجة مخلف تخليـلـل الصلــبـ بــالكحول

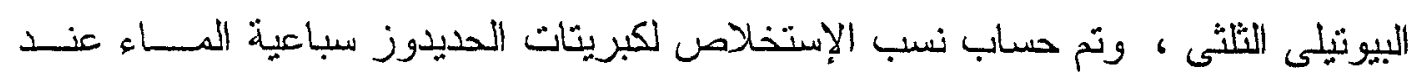

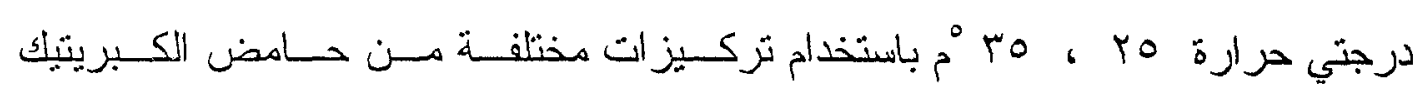

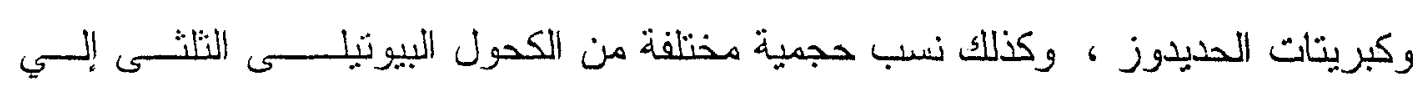
المحلول.

- ويوصى بأن يكون تركيز الحامض أقل ما يمكن ويكون تركيز كبرينـات الحديدوز أعلى

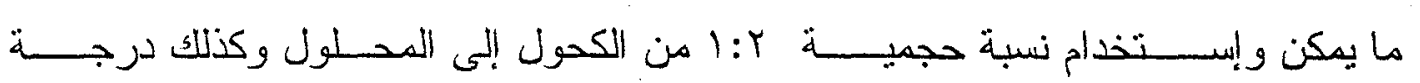

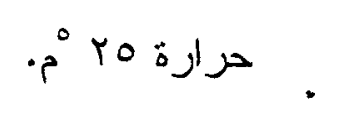

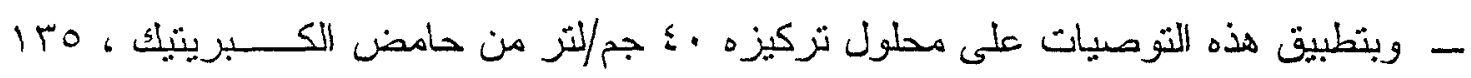

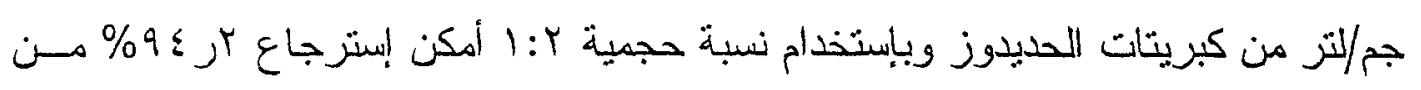

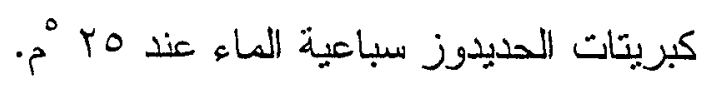

